\title{
Species diversity of Rhizophora in Tambelan Islands, Natuna Sea, Indonesia
}

\author{
AHMAD DWI SETYAWAN ${ }^{1, \boldsymbol{\gamma}}$, YAYA IHYA ULUMUDDIN ${ }^{2}$ \\ ${ }^{1}$ Department of Biology, Faculty of Mathematics and Natural Sciences, Sebelas Maret University. Jl. Ir. Sutami 36A 57126 Surakarta, Central Java, \\ Indonesia. Tel./Fax.+62-271-663375, `email: volatileoils@gmail.com. \\ ${ }^{2}$ Research Center for Oceanography, Indonesian Institute of Sciences (PPO-LIPI), East Ancol, North Jakarta 14430, Indonesia.
}

Manuscript received: 16 April 2012. Revision accepted: 17 October 2012.

\begin{abstract}
Setyawan AD, Ulumuddin YI. 2012. Species diversity of Rhizophora in Tambelan Islands, Natuna Sea, Indonesia. Biodiversitas 13: 172177. Research on diversity and distribution of mangroves on the small remote islands are rarely performed than on the coastal area and estuaries. Tambelan Islands is a cluster of small islands isolated in the Natuna Sea, Indonesia. On the island there are four species of Rhizophora, namely $R$. apiculata, $R$. stylosa, R. mucronata, and hybrid species $R$. x lamarckii. Rhizophora stylosa and $R$. apiculata are the most common species found. $R$. mucronata only found in certain places (i.e. Durian River), $R$. $x$ lamarckii rare, usually grows in stands that also covered by the two parental, R. stylosa and $R$. apiculata. All Rhizophora species were found to have thorn on the leaf tip, and spotted brown on the underneath leaf. $R$. apiculata has a petal without woolly feathers, inflorescence have short stalks and cork. $R$. stylosa and $R$. mucronata are sibling species, both of them have a long-stalks and dichotomy inflorescence, but the style of $R$. mucronata very short $(<2.5 \mathrm{~mm})$, whereas in $R$. stylosa longer $(>2.5 \mathrm{~mm}) . R$. x lamarckii has characters between $R$. apiculata and $R$. stylosa.
\end{abstract}

Key words: Rhizophora, diversity, Tambelan, Natuna Sea

Stilt mangroves are widespread throughout most tropical coastal areas of Indo-Malaya, from the east Africa to western Pacific (Duke 2006; Giesen et al. 2006). This group of the genus Rhizophora consists of three species, $R$. mucronata, $R$. stylosa (two being closely allied or sibling species) and $R$. apiculata, and two hybrids, $R . \times$ lamarckii (from $R$. apiculata $\times R$. stylosa) and $R$. $\times$ annamalayana (from $R$. apiculata $\times R$. mucronata) (Duke 2006). The five species can be found in Indonesia. $R$. apiculata and $R$. stylosa is the most common species found. $R$. mucronata relatively rare, although its global distribution much wider than the two other Rhizophora species (Hou 1992; Duke 2006; Duke et al. 2010a,b,c). R. x lamarckii rarely found, only in locations where both parents present. $R . \times$ annamalayana Kathiresan (Kathiresan 1995; 1999) only once recorded in Indonesia, i.e. in Lombok Island, West Nusa Tenggara, and originally named R. lombokensis Baba \& Hayashi (Baba 1994). The main distribution of this hybrid is the east coast of India (Pichavaram, Tamil Nadu), Sri Lanka and the Andaman and Nicobar Islands (Ragavan et al. 2011; Dahdouh-Guebas 2012).

Tambelan Islands is a group of small islands located in the Natuna Sea, Indonesia between Kalimantan, Sumatra and the Malay Peninsula, with the coordinates of $0^{\circ} 2$ "$1^{\circ} 25^{\prime \prime} \mathrm{N}$ and $106^{\circ} 50 "-107^{\circ} 40^{\prime \prime} \mathrm{E}$ (IOTA 2007). Tambelan Islands consist of 77 islands; but the exact number is debatable, since some small islands rise and submerged by the tide, about 20 islands are inhabited or used for agricultural field. The total area of land is 169.42 acres, while the ocean is 58993.42 acres, with a population of about 4738 inhabitants (BPS Bintan 2008). The two largest islands and inhabited by majority population are Tambelan (Tambelan Besar) and Benua. Uwi is important for natural conservation, since it is the main spawning spot turtles on the islands. The Tambelan Islands have hilly topography. At the last glacial maximum period, this region is the mountain peaks near the North Sunda super-river that empties into the Natuna Sea (Steinke et al. 2008). Marine waters of Tambelan Islands have about 0.5 to $2 \mathrm{~m}$ wave height (Bull Meteor 2009). Based on the satellite image data processing ALOS AVNIR-2 (earth.esa.int), in 2010, the mangrove ecosystem of these islands covered an area of 478.2 hectares (data not shown). Setyawan and Ulumuddin (2012) noted the existence of two species of Bruguiera, ie $B$. cylindrica and $B$. sexangula in the islands.

In Tambelan Islands, there is no major river; the mangrove ecosystem is marine type with relatively high levels of salinity. Stilt mangroves grow on various types of substrates, such as fertile mud sediments, white sand, and corals. Typically, these mangroves are common in the midinter-tidal zone, and particularly along the seaward margin of mangrove stands, especially for $R$. apiculata and $R$. stylosa. Stilt mangroves are known to play a vital role in shoreline protection, enhancement of water quality in nearshore environments (including coral reefs), and in supporting food chains. This tree is often harvested for firewood, and sometimes is used for building materials. Stilt mangroves are very well known by the Tambelan 
population, generally named "bakau". The Malays, as the major populations, recognize R. apiculata as bakau minyak, $R$. stylosa as bakau (pasir) and $R$. mucronata as bakau kurap; although it is sometimes confusing.

This study aims to determine the diversity of Rhizophora species in the Tambelan Islands, Natuna Sea, Indonesia.

\section{MATERIALS AND METHODS}

\section{Area study}

Several series of survey had been conducted within two weeks in the end of 2010 in Tambelan Islands, Natuna Sea, Indonesia. A total of 23 islands was explored, namely Uwi, Sedulang Besar, Sedulang Kecil, Sedua Besar, Sedua Kecil, Bungin, Tambelan (Tambelan Besar), Genting, Mundaga, Lintang, Panjang, Tamban, Ibul, Nibung, Nangka, Lesuh, Benua, Bedua (incl. Untup Darat), Jelak (incl. Burung), Selentang, Betung, Lipih, Kepala Tambelan, Menggirang, and Menggirang Kecil. On the quite large Tambelan Island, the exploration was conducted at four locations, namely: Suak (canal) Dadu and Suak Ganja located in the Tambelan Bay, and Durian River and Telukkupang River (incl. Kera Island) in the northwestern part of Tambelan. The list of exploration sites had been previously set based on the satellite imagery of ALOS AVNIR-2 in 2010, topographic maps of the Tambelan Islands with the scale of 1:75,000, and a preliminary study of a few months before.

Based on satellite imaginery and field surveys, as many as seven islands were covered with mangrove ecosystem characterized by a group of mangrove tree habitat $(>100$ ha), namely Bedua, Benua, Burung, Ibul, Menggirang, Selentang, Tambelan (in four locations). Based on field survey, mangroves are also present in many other islands, but the quantity is very limited (Figure 1).

\section{Procedures}

Field surveys. Mangrove habitat is entered from the seaward using rubber boats. Further searching was done along the edge of the mangrove forest, followed by walking through the canals in the mangrove forest or directly through the pneumatophore to know the conditions in the forest. At the locations where the water was deep enough and the trunks were too tight to pass such as in the surrounding of the Durian River and Telukkupang River, the exploration was done only by boat; the crocodiles that inhabited those places were also a consideration in itself.

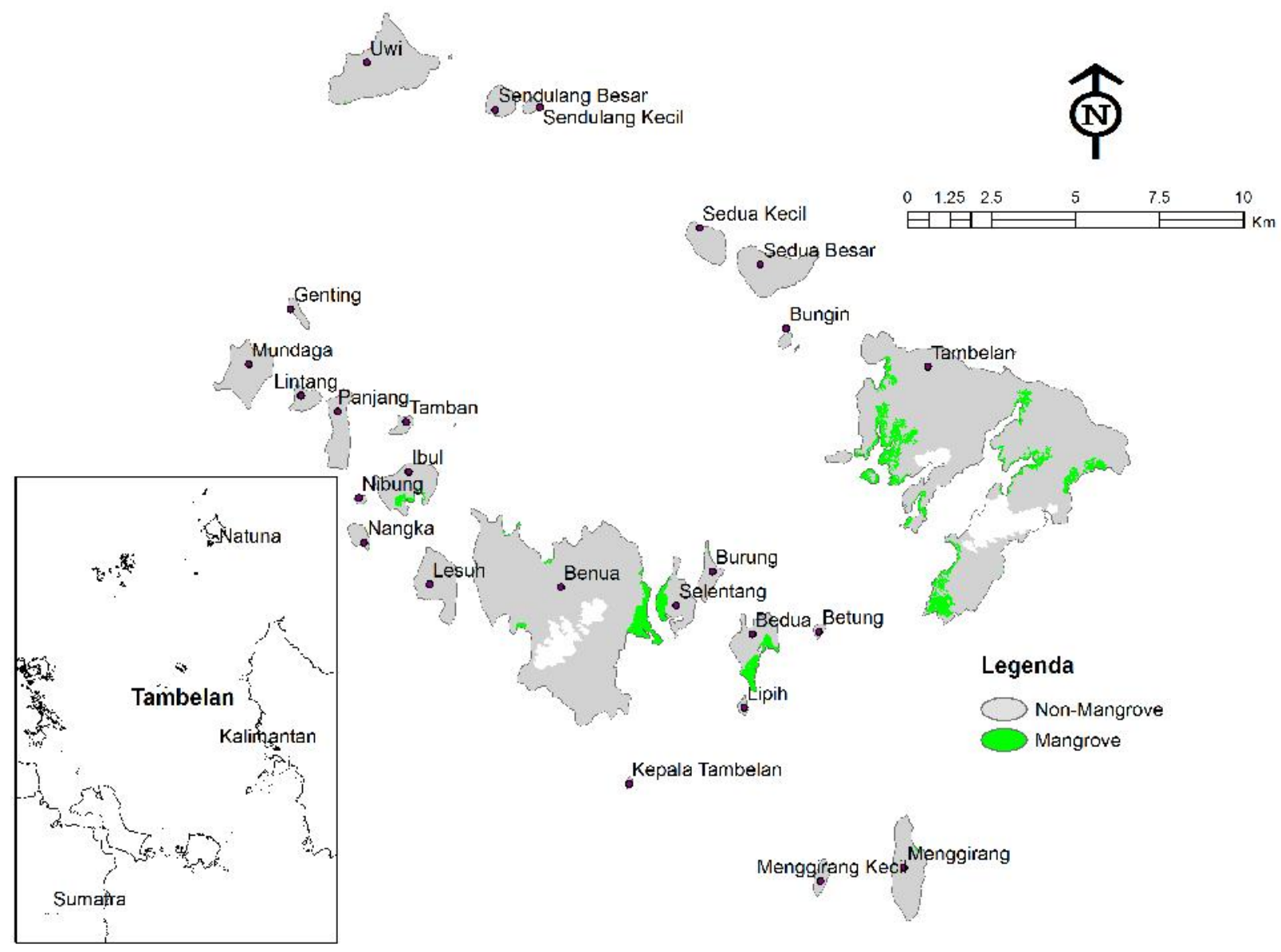

Figure 1. The distribution of mangrove ecosystems in Tambelan Islands, Natuna Sea, Indonesia 
On small islands, the exploration was done along the coastal areas as far as possible, even in some small islands such as Lipih, the exploration was done by walking around the island beaches, while on the island with a steep and wavy coastline such as Sedulang Kecil, the exploration was done by boat around the island. The exploration was expected to represent all parts of the island potentially covered with mangroves.

Sample observations. Each species of Rhizophora was found in every location sampled as many as 2-5 specimens and each sample was supposed to have flowers and hypocotyls. Samples were observed directly on the sites in a fresh condition and documented, then dried and made into herbarium and again observed in the laboratory. The preparation of dried herbarium samples was carried out according to Lawrence (1951). Herbarium specimens were stored at the Research Center for Oceanography, Indonesian Institute of Sciences (PPO-LIPI), Jakarta. Further herbarium samples were observed with reference to Rifai (1976) and de Vogell (1987), i.e. the samples were grouped according to morphological similarities and each species was observed for the first 10 samples, then the identification key was made, after that all remaining samples were observed, and described by adding the character as fresh specimens. The identification was done by referring to Backer and Bakhuizen v.d. Brink (1968), Tomlison (1986), $\mathrm{Ng}$ and Sivasothi (1999), Giesen et al. (2006), and Duke (2006), Qin and Boufford (2007). The ecological characteristic and others were also referred to Giesen et al. (2006), and Duke et al. (2010a,b,c). The conservation status was referred to IUCN (2012).

\section{RESULTS AND DISCUSSION}

\section{Keys of identification}

\section{Rhizophora Linnaeus, Sp. Pl. 1: 443.1753}

Trees are with stilt roots, usually branching and several metres from the trunk. Stem internodes are hollow. Stipules are reddish, sessile, leaflike, interpetiolar, lanceolate. Leaves are opposite or distichous, cauline, leathery, petiolate, simple. Leaf blades are glabrous, entire; elliptic, or obovate (usually elliptic to obovate); pinnately veined (midrib extended into a caducous point); margin is entire or serrulate near apex. Inflorescences axillary, dense cymes (simple or di- or trichasial); pedunculate. Flowers are ebracteate; bracteoles forming a cup just below flower; usually 4 or 5 merous. Perianth is with distinct calyx and corolla; 6-32; 2 -whorled; isomerous. Calyx tube is ovate (to narrowly ovate), adnate to ovary, persistent; lobes 5-8. Petals are 4, ovate; sessile, alternating with the calyx, lanceolate; blunt-lobed; valvate; tubular; regular; commonly fleshy (or leathery); persistent. Stamens are 812; filaments are much shorter than anthers or absent; free of one another; anthers are connivent; dorsifixed; dehiscing by longitudinal valves, introrse, locules many, dehiscing by an adaxial valve. Ovary is inferior, 2-loculed, apically partly surrounded by a disk, free part elongating after anthesis; style 1, sometimes very short; stigmas are 4 . Fruit is brown, ovoid, ovoid- conic, or pyriform. Fertile seed is 1 per fruit; germination viviparous; hypocotyl protruding to $78 \mathrm{~cm}$ before propagule falls (Ko 1983; Gathe and Watson 2008)

Eight or nine species: tropics and subtropics; five species in Indonesia; four species in Tambelan Islands.

1a. Peduncle is shorter than petiole, thick, on leafless stems; flowers are 2 per inflorescence; bracteoles united, cupshaped; petals are glabrous; stamen is 9-15.

2a. Bracts are corky brown, flower are hairless .. R. apiculata 2 b. Bracts are smooth green .................. R. x lamarckii

1b. Peduncle is usually as long as (or greater than) petiole, slender, in leaf axil; flowers are more than 2 per inflorescence; bracteoles are united at base; petals are pubescent; stamen is 6-8.

3a. Style is $0.5-1.5 \mathrm{~mm}$ (less than $2.5 \mathrm{~mm}$ ); anthers are sessile .......................................... R. mucronata

3b. Style is $4-6 \mathrm{~mm}$ (greater than $2.5 \mathrm{~mm}$ ); anthers are on a short but distinct filament ............ R. stylosa

\section{Description}

Rhizophora apiculata Blume, Enum. Pl. Javae 1: 91. 1827

Synonyms. Mangium candelarium Rumph., Rhizophora candelaria Candolle, Rhizophora conjugata (non Linné) Arn., Rhizophora lamarckii, Rhizophora mangle (non Linné).

Local name. Bakau minyak, bakau tandok, bakau akik, bakau puteh, akik (Mal.); Bakau, bakau minyak, bangka minyak, donggo akit, jankar, abat, bangkita, bangkita baruang, kalumagus, kailau, parai (Ind.).

Description. Trees are erect, 3-6 (-30) $\mathrm{m}$ tall, and 50 $\mathrm{cm}$ d.b.h. Stilt-roots are up to $5 \mathrm{~m}$ up the stem. Bark is dark grey and chequered, usually with vertical fissures. Stipules are 4-(6)-8 cm, dropped early. Leaves are crowded at twig tips, opposite, simple, penni-veined but venation barely visible, glabrous, narrowly elliptic, leathery; are dark green with a distinct light green zone along the midrib, tinged reddish underneath. Petiole is $1.5-3.5 \mathrm{~cm}$, usually tinged reddish; and is flanked by leaflets at its base, $4-8 \mathrm{~cm}$. Leaf blade is elliptic-oblong to sublanceolate, $7-19 \times 3-8 \mathrm{~cm}$, abaxial midvein reddish, base broadly cuneate, apex acute to apiculate. Inflorescences are 2-flowered cymes; peduncle is $0.7-10 \mathrm{~mm}$. Flowers ca. are $2 \mathrm{~cm}$ diam., sessile, yellow-red, placed in axillary bundles, stalk $1.4 \mathrm{~cm}$ long. Calyx lobes are ovate, concave, 1-1.4 cm, apex acute. Sepals are 4,yellow-red, persistent, in a recurved form on the end of the fruit. Petals are lanceolate, flat, 6-8 mm, membranace- ous, glabrous, white. Petals are 4, yellowwhite, membranous, flat, hairless, 9-11 mm long. Stamens are mostly 12, 4 adnate to base of petals, 8 adnate to sepals, 6-7.5 mm; anthers are nearly sessile, apex apiculate. Ovary is largely enclosed by disk, free part $1.5-2.5 \mathrm{~mm}$; style is ca. $0.8-1 \mathrm{~mm}$. Fruit ca. is $2.5 \times 1.5 \mathrm{~cm}$, apical half 
narrower, contain one fertile seed. Hypocotyl is cylindricclavate, green with purple, club shaped, ca. 1.8-3.8 $\times 1-2$ $\mathrm{cm}, \pm$ blunt before falling.

Ecology. Occurs on deep, soft, muddy soils that are flooded by normal high tides. Avoids are firmer substrates mixed with sand. Dominant: may form up to $90 \%$ of the vegetation at a site (Giesen et al. 2006).

Distribution. From Sri Lanka throughout Southeast Asia to Australia and the western Pacific Islands. In Tambelan Islands found in nine coastal regions namely: Tambelan (Suak Dadu, Suak Ganja, Telukkupang River, Durian River), Benua, Ibul, and Uwi Islands.

Conservation status. Least Concern ver 3.1.

Uses. The roots are sometimes used as anchors. The wood is used as fire-wood, for construction and for charcoal making.

Taxonomic note. The species ephitet "apiculata" means "pointed out". It differs from $R$. mucronata and $R$. stylosa in possessing short, stout, dark grey inflorescence stalks (vs. long, slender, yellow).

\section{Rhizophora x lamarckii Montrouz. Mém. Acad. Roy.}

Sci. Lyon, Sect. Sci. sér. 2, 10:201. 1860

Rhizophora $x$ lamarckii is a hybrid of $R$. apiculata and R. stylosa. This species has many similarities with its parents.

Local name. Unknown

Description. It has erect trees and shrubs up to ca. 25 $\mathrm{m}$, often with several trunks; bark is light brown, smooth to dark grey, rough, and often horizontally fissured. Stilt roots extend to 2(-6) $\mathrm{m}$ above the ground, extend downwards from branches. Stem base is diminished below the stilt roots. Leaves are simple, opposite, obovate-elliptic to elliptic, bright yellowish-green, waxy above and dull below, 7-15 cm long, 3-8 cm wide, yellow-green, with a pointed apex and mucronate spike to $6 \mathrm{~mm}$ long, and are not evenly spotted below (but old leaves are often liberally wound-spotted); petiole is 1-4 cm long. Inflorescence is axillary, 2-4-flowered (occasionally 1), borne within the leafy shoot; yellow-green or cream flowers which are held within leaf clusters; peduncle is 1-3 cm long, green,smooth; bracteoles are partly united, smooth, yellow-green except a brown crenulate rim. Flowers have 4 calyx lobes and 4 slightly hairy white petals. Petals c. are $10 \mathrm{~mm}$ long; margins slightly incurved, sparsely hairy. Stamens are variable, usually 9-11; anthers sessile. Upper part of ovary is shallowly conical; style c. are $2.5 \mathrm{~mm}$ long; stigma minutely 2-lobed. Fruit is rarely found beyond the immature fruit stage. Fruit is shiny, brown-olive, inverted pear-shape, pyriform, 2.5-3 cm long. Hypocotyl is rarely developed, smooth, green, 14-28 cm long, narrowly clubshaped, rounded at apex.

Ecology. Occurs in locations that are found both parents (R. apiculata and R. stylosa), both deep, soft, muddy soils that are flooded by normal high tides and firmer substrates are mixed with sand. Dominant: relatively rare, but spreading evenly; rarely produces fertile propagules, but it is capable of asexual reproduction by dividing and spreading over large areas.
Distribution. Its distribution is overlapping to its parents. From India throughout Islands of Southeast Asia to tropical Australia. In Tambelan Islands, it is found in four coastal regions namely: Tambelan (Durian River), Benua, Ibul, and Uwi Islands.

Conservation status. This hybrid species has not yet been assessed for the IUCN Red List.

Uses. The wood is used as fire-wood, for construction and for charcoal making.

Taxonomic note. The species ephitet "lamarckii" is named in honour of Jean Baptiste Antoine Pierre de Monnet de Lamarck (1744-1829), the French botanist famous for his theory of acquired traits in evolution.

\section{Rhizophora mucronata Lamarck ex Poiret, Encycl. 6: 189. 1804}

Sinonyms. Mangium candelarium Rumphius, Rhizophora candelaria Wight \& Arn., Rhizophora latifolia Miq., Rhizophora longissima Blanco, Rhizophora macrorrhiza Griff., Rhizophora mangle (non Linné) Roxb., Rhizophora mucronata var. typica Schimp.

Local name. Bakau kurap, Bakau belukap, Bakau gelukap, Bakau jankar, Bakau hitam, (Mal.) Bangka Itam, Dongoh Korap, Bakau Hitam, Bakau Korap, Bakau Merah, Jankar, Lenggayong, Belukap, Lolaro (Ind.).

Description. It has erect trees and shrubs, and is up to 27(-30) $\mathrm{m}$, d.b.h. is up to $70 \mathrm{~cm}$ in diam; bark is dark to almost black, horizontally fissured. It has both stilt roots and aerial roots growing from lower branches. Stipules are $5.5-8.5 \mathrm{~cm}$. Petiole is $2.5-4 \mathrm{~cm}$. Leaf blade is broadly elliptic to oblong, 8.5-23 $\times 5-13 \mathrm{~cm}$, leathery, base cuneate, apex \pm blunt to \pm acute. Leaf stalk is green, $2.5-5.5 \mathrm{~cm}$ long, leaflets are at the base of leaf stalk $5.5-8.5 \mathrm{~cm}$. Inflorescences are forked 2-3 times, 2-5(-12)-flowered cymes; peduncle is $2.5-5 \mathrm{~cm}$. Flowers are sessile. Calyx lobes are ovate, 9-14 $\times 5-7 \mathrm{~mm}$, deeply lobed, pale yellow. Petals are lanceolate, 7-9 $\mathrm{mm}$, fleshy, partly embracing stamens, margins pilose (densely hairy margins). Stamens are 8,4 borne on base of petals, 4 borne on sepals, $6-8 \mathrm{~mm}$; anthers sessile. Ovary emerges far beyond disk, free part elongate-conic, 2-3 mm; style is $0.5-1.5 \mathrm{~mm}$. Fruit is dull, brownish green, elongate-ovoid, 5-7 × 2.5-3.5 cm, basally often tuberculate, apically slightly contracted. Hypocotyl is cylindric, $30-65 \mathrm{~cm}$ long, up to $2 \mathrm{~cm}$ wide.

Ecology. They are found in similar localities as $R$. apiculata but more tolerant to sandy and firmer bottoms.

Distribution. From East Africa throughout Southwest Asia, South Asia, Southeast Asia, East Asia, tropical Australia, to Western Pacific Islands. In Tambelan Islands is only found in Tambelan (Durian River).

Conservation status. Least Concern ver 3.1.

Uses. The timber is used for firewood and charcoalmaking.

Taxonomic note. The species ephitet "mucronate" means "leaf apex usually broad, terminated by a short stiff point called a mucro". The Malay name refers to their fruit, kurap means "warty". $R$. mucronata differs from $R$. apiculata in possessing long, slender, yellow inflorescence stalks (vs. short, stout, dark grey) and from $R$. stylosa in the 0.5-1.5 mm long style in the flower (vs. 4-6 mm long). 


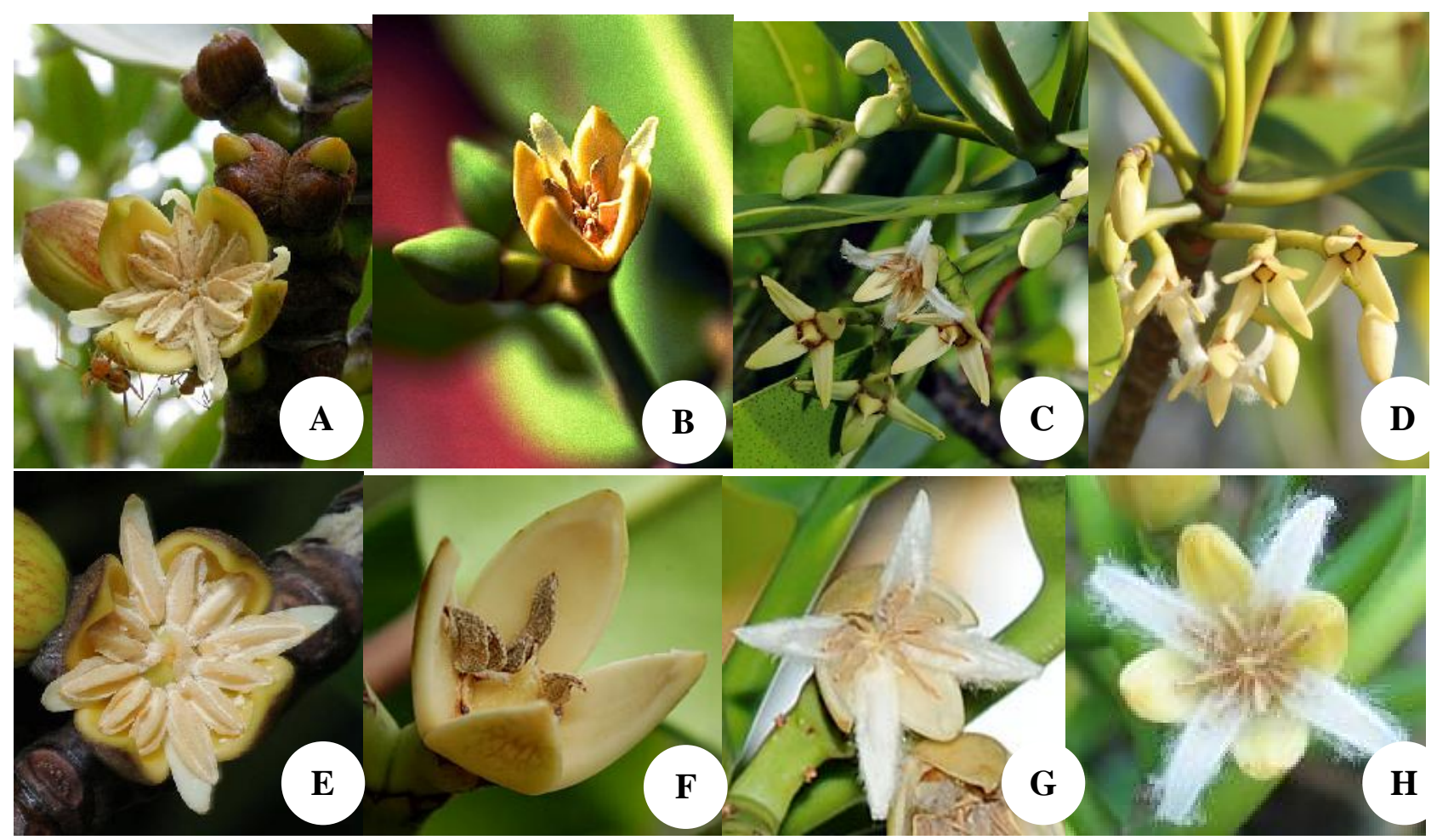

Figure 2. Diagnostic characters of Rhizophora on Tambelan Islands, Natuna Sea, Indonesia. Inflorescense: A. $R$. apiculata, B. $R . x$ lamarckii, C. R.mucronata, D. R. stylosa; Flowers: E. R. apiculata, F. R. x lamarckii, G. R.mucronata, H. R. stylosa (photo: many sources)

\section{Rhizophora stylosa Griffith, Not. Pl. Asiat. 4: 665. 1854}

Synonyms. Rhizphora lamarckii, Rhizophora mucronata Lamarck var. stylosa (Griffith) Schimper.

Local name. Generally the same names as for Rhizophora mucronata (Bakau in Indonesia and Malaysia); well known as Bakau pasir in Singapore.

Description. It has multi- or single-trunked erect small trees or shrubs, often less than $8 \mathrm{~m}$ up to $10 \mathrm{~m}$ tall. Bark is reddish or pale gray, smooth to rough, fissured; it is $10-15$ $\mathrm{cm}$ at d.b.h.; stilt-roots are up to $3 \mathrm{~m}$ long, and aerial roots emerge from the lower branches. Leaves are broadly elliptic,; leaf blade is obovate, $6.5-12.5 \times 3-4(-5.5-7.5) \mathrm{cm}$, base broadly cuneate, apex mucronate, leathery, with a regularly-spotted lower surface and a pointed tip. Petiole is 1-3.5 cm, with 4-6 cm long leaflets at its base. Inflorescences are axillary, flowers are forked 3-5 times, with 2- to many (up to 32) flowered; peduncle is $1-5 \mathrm{~cm}$. Pedicel 5-10 $\mathrm{mm}$, terete; bracteoles are brown, connate. Calyx lobes are pale-yellow, still present on the fruit, but are then recurved, lanceolate to oblong- lanceolate, 9-12 $\times$ 3-5 mm. Petals are white-yellow, 0.8-1.2 cm, involute, margin densely villous/woolly. Stamens are usually 8 ; filaments are short but distinct; anthers are 5-6 mm. Ovary is emerging beyond disk, free part and shallowly conic and less than $1.5 \mathrm{~mm}$; style is $4-6 \mathrm{~mm}$; stigma lobes are 2 . Fruit is green-brown, conic, pear-shaped, $2.5-4 \times$ ca. $2 \mathrm{~cm}$. Hypocotyl is cylindric (often mistaken for the 'fruit'), 20 $40 \mathrm{~cm}$, apex acute. Flowers and fruits are produced throughout the year.
Ecology. It grows in a variety of tidal habitats on mud, sands, coarse grits and rock, pioneering in coastal environments or on landward margins of mangroves. One typical niche is in the fringing mangroves of small 'coral' islands, growing on coral substrate.

Distribution. From Sri Lanka, Southeast Asia throughout South China, Ryukyu Islands to tropical Australia and the western Pacific Islands. In Tambelan Islands, it is found in nine coastal regions namely: Tambelan (Suak Ganja, Telukkupang River, Durian River), Burung, Benua, Lipih, Ibul, and Uwi Islands.

Conservation status. Least Concern ver 3.1.

Uses. The timber is used for fire-wood, for construction and for charcoal making.

Taxonomic note. The species ephitet "stylosa" is Latin and comes from 'stylos' which means 'pillar' and refers to the long style of this species. $R$. mucronata and $R$. stylosa, the sibling species, are distinguished by short styles $(<2.5$ $\mathrm{mm}$ long) in $R$. mucronata, while $R$. stylosa has long styles (>2.5 mm long). According to Duke et al. (2002) both species are genetically and morphologically similar.

Note. The only mangrove species of Indo-Malayan region that is not found in Tambelan is $R$. annamalayana, a hybrid species between $R$. apiculata and $R$. mucronata. The main distribution of this hybrid is the east coast of India, Sri Lanka and the Andaman and Nicobar Islands. The western distribution of $R$. stylosa is not reaching these regions, except for a little stand in Orissa and Andaman 
and Nicobar states (Ellison et al. 2012), so that hybridization occurs only between $R$. apiculata and $R$. mucronata. Meanwhile, in Nusantara (Malesia), there are plenty of $R$. stylosa that density is often higher than $R$. mucronata, so more frequent hybridization between $R$. apiculata and $R$. stylosa generate $R$. x lamarckii. The nature style of $R$. stylosa is much longer than the style of $R$. mucronata, and it is thought to increase the success of hybridization between $R$. stylosa and $R$. apiculata. However, in Nusantara there are also notes about the presence of $R$. annamalayana, in Merbok, Malay Peninsula (Chan 1996) and Lombok, West Nusa Tenggara, originally named R. lombokensis (Baba 1994).

\section{CONCLUSION}

On Tambelan islands, there are four species of Rhizophora, namely $R$. apiculata, $R$. stylosa, $R$. mucronata, and hybrid species $R$. x lamarckii. Rhizophora stylosa and $R$. apiculata are the most common species found. $R$. mucronata is only found in certain places (i.e. Durian River), $R$. $x$ lamarckii is rare, and it usually grows in stands that are also covered by the two parental species, i.e. $R$. stylosa and $R$. apiculata. All Rhizophora species were found to have thorn on the leaf tip, and spotted brown on the underneath leaf. $R$. apiculata has a petal without woolly feathers, inflorescence has short stalks and cork. R. stylosa and $R$. mucronata are sibling species, both of them have a long-stalks and dichotomy inflorescence, but the style of $R$. mucronata is very short $(<2.5 \mathrm{~mm})$, whereas $R$. stylosa is longer (> $2.5 \mathrm{~mm}) . R$. $x$ lamarckii has mixed characters between $R$. apiculata and $R$. stylosa.

\section{ACKNOWLEDGEMENTS}

The research was funded through the Research Project "Natuna Sea Expedition - 2010" in collaboration with the Directorate General of Higher Education, Ministry of National Education, GoI and the Research Center for Oceanography of Indonesian Institute of Science (PPOLIPI) Jakarta. The author would like to thank Dr. Dirhamsyah as the chairman of the project, Fahmi as the coordinator of field researchers, Daniel Irham as captain of the Research Ship of Baruna Jaya VIII, and Murtada village chief of Kampung Melayu who acting as field guide and informant.

\section{REFERENCES}

Baba S. 1994. New natural hybrid in Rhizophora. Mangroves, Newsletter of the International Society of Mangrove Ecosystems 13: 1.

Backer CA, Bakhuizen van den Brink, RC Jr. 1968. Flora of Java. Vol. III. P.Noordhoff, Groningen.

BPS Bintan. 2008. Bintan in figures in 2007. BPS Kabupaten Bintan, Tanjung Pinang. [Indonesia]
Bull Meteor. 2009. Evaluation of weather and rainy characteristic in October 2009 as well as weather and rainy characteristic in November 2009. Stasiun Meteorologi Klas I Hang Nadim. Batam. Bulletin Meteorologi Edisi 23, November 2009. [Indonesia]

Chan HT. 1996. A note on the discovery of Rhizophora $x$ lamarckii in Peninsular Malaysia. J Trop For Sci 9: 128-130.

Dahdouh-Guebas F. 2012. Rhizophora annamalayana Kathiresan. In: Dahdouh-Guebas F (ed.). World mangroves database. http://www.vliz.be/vmdcdata/mangroves/aphia.php? $\mathrm{p}=$ taxdetails\&id= 344744

de Vogel EF. 1987. Guidelines for the preparation of revisions. In: de Vogel EF (ed). Manual of herbarium taxonomy theory and practice. UNESCO, Jakarta

Duke NC. 2006. Australia's mangroves: The authoritative guide to Australia's mangrove plants. University of Queensland, Brisbane.

Duke N, Kathiresan K, Salmo III SG, Fernando ES, Peras JR, Sukardjo S, Miyagi T. 2010a. Rhizophora apiculata. In: IUCN 2012. IUCN Red List of Threatened Species. Version 2012.2. www.iucnredlist.org. On 15 November 2012.

Duke N, Kathiresan K, Salmo III SG, Fernando ES, Peras JR, Sukardjo S, Miyagi T. 2010b. Rhizophora mucronata. In: IUCN 2012. IUCN Red List of Threatened Species. Version 2012.2. www.iucnredlist.org. On 15 November 2012.

Duke NC, Lo EYY, Sun M. 2002. Global distribution and genetic discontinuities of mangroves-emerging patterns in the evolution of Rhizophora. Trees Struct Funct 16: 65-79.

Duke NC. 2006. Rhizophora apiculata, R. mucronata, $R$. stylosa, $R . \times$ annamalayana, $R . \times$ lamarckii (Indo-West Pacific stilt mangroves), ver. 2.1. In: Elevitch, C.R. (ed.). Species Profiles for Pacific Island Agroforestry. Permanent Agriculture Resources (PAR), Hōlualoa, Hawai'i. www.traditionaltree.org.

Ellison J, Duke N, Kathiresan K, Salmo III SG, Fernando ES, Peras JR, Sukardjo S, Miyagi T. 2010. Rhizophora stylosa. In: IUCN 2012. IUCN Red List of Threatened Species. Version 2012.2. www.iucnredlist.org. On 15 November 2012.

Gathe J, Watson L. 2008. Rhizophora L. FloraBase the Western Australia Flora. http://florabase.dec.wa.gov.au/browse/profile/21806

Giesen W, Wulffraat S, Zieren M, Scholten L. 2006. Mangrove guidebook for Southeast Asia. FAO and Wetlands International

Hou D. 1992. Rhizophora mucronata Poiret. In: Lemmens RHMJ, Wulijarni-Soetjipto N (eds.): Plant Resources of South-East Asia. No. 3: Dye and tannin-producing plants. Prosea Foundation, Bogor.

IUCN 2012. IUCN Red List of Threatened Species. Version 2012.2. www.iucnredlist.org

Kathiresan K. 1999. Rhizophora annamalayana Kathir (Rhizophoraceae), a new Nothospecies from Pichavaram mangrove forest in Southeastern peninsular India. Environ Ecol 17 (2): 500-501.

Kathiresan K. 1995. Rhizophora annamalayana: A new species of mangroves. Environ Ecol 13 (1): 240-241.

Ko WC. 1983. Rhizophoraceae. In: Fang WP, Chang CY (eds.) Fl Reipubl Popularis Sin 52 (2): 125-143.

Lawrence GHM. 1951. Taxonomy of vascular plants. John Wiley and Sons, New York.

Ng PKL, Sivasothi N (eds). 2001. A guide to mangroves of Singapore. Volume 1: The ecosystem and plant diversity and Volume 2: Animal diversity. The Singapore Science Centre, Singapore.

Ong JE. 2003. Plants of the Merbok Mangrove, Kedah, Malaysia and the urgent need for their conservation. Folia Malaysiana 4 (1): 1-18.

Qin HN, Boufford DE. 2007. Rhizophoraceae. In: Wu ZY, Raven PH, Hong DY (eds). Flora of China 13: 295-299.

Ragavan P, Saxena M, Coomar T, Saxena A. 2011. Preliminary study on natural hybrids of genus Rhizophora in India. ISME/GLOMIS Electronic Journal 9:5

Rifai MA. 1976. Principles of systematic botany. Lembaga Biologi Nasional, LIPI, Bogor. [Indonesia]

Setyawan AD, Ulumuddin YI. 2012. Species diversity and distribution of Bruguiera in Tambelan Islands, Natuna Sea, Indonesia. Proc Soc Indon Biodiv Intl Conf 1: 82-90.

Steinke S, Hanebuth SJJ, Vogt C, Stattegger K. 2008. Sea level induced variations in clay mineral composition in the southwestern South China Sea over the past 17,000 yr. Marine Geol 250 (3-4): 199-210

Tomlinson PB. 1986. The botany of mangroves. Cambridge University Press, London. 